\title{
Pengaruh Penambahan 1,4-Butanadiol dan Polietilen Glikol (PEG) 1000 terhadap Kemudahan Biodegradasi Bioplastik dari Biji Nangka (Artocarpus heterophyllus)
}

\author{
Argo Khoirul Anas ${ }^{\text {a }}$, Nanang Rudianto Ariefta ${ }^{\text {b }}$, Yuni Nurfiana ${ }^{\text {b }}$, Eli Rohaeti ${ }^{\text {c }}$ \\ ${ }^{a}$ Progran Studi Kimia, Universitas Islam Indonesia, email: argokhoirulanas@uii.ac.id \\ ${ }^{\mathrm{b}}$ Jurusan Kimia, Universitas Gadjah Mada \\ ${ }^{\mathrm{c}}$ Jurusan Pendidikan Kimia, Universitas Negeri Yogyakarta
}

\begin{abstract}
The influences of plasticizer on the biodegradability of bioplastic film synthesized from starch obtained from jackfruit seeds with a help of Acetobacter xylinum were investigated. In this study, 1,4butanediol and polyethylene glycol (PEG) 1000 were used as plasticizer. The biodegradation behavior of the resulted bioplastic films was characterized by calculating changes in their mass loss and rate of mass loss. The Fourier Transform Infrared (FTIR) spectroscopy was also conducted to analyze their functional group. The results shows that all the bioplastic films were well biodegradated, where PEG 1000 with concentration of $0,5 \%$ and $1,0 \%$ can successfully improve the biodegradability of bioplastic film. Meanwhile, the used of 1,4-butanediol with concentration of $0,5 \%$ and $1,0 \%$ can increase and decrease the biodegradability of sample, respectively.
\end{abstract}

Keyword: Acetobacter xylinum, Jackfruit Seeds, Bioplastic, Plasticizer

\begin{abstract}
ABSTRAK
Penelitian ini bertujuan untuk mempelajari pengaruh penambahan bahan pemlastis terhadap biodegradabilitas film bioplastik dari pati biji nangka dengan bantuan Acetobacter xylinum. Dalam hal ini, zat pemlastis yang digunakan adalah 1,4-butanadiol and polietilen glikol (PEG) 1000. Biodegradibilitas film bioplastik dikarakterisasi dengan cara menghitung nilai kehilangan massa dan laju kehilangan massanya. Gugus fungsi yang terdapat dalam sampel dikarakterisasi menggunakan spektroskopi Fourier Transform Infrared (FTIR). Hasil penelitian menunjukkan bahwa semua sampel film bioplastik dapat terdegradasi dengan baik, di mana PEG 1000 dengan konsentrasi 0,5\% mampu meningkatkan biodegradabilitas film bioplastik. Sementara itu, penggunaan 1,4-butanadiol dengan konsentrasi $0,5 \%$ dan $1,0 \%$, berturut-turut, mampu meningkatkan dan menurunkan biodegradabilitas sampel.
\end{abstract}

Kata Kunci: Acetobacter xylinum, Biji Nangka, Bioplastik, Pemlastis

Pengaruh Penambahan 1,4-Butanadiol dan Polietilen Glikol (PEG) 1000 terhadap

Kemudahan Biodegradasi Bioplastik dari Biji Nangka (Artocarpus heterophyllus)

(Argo Khoirul Anas, Nanang Rudianto Ariefta, Yuni Nurfiana, Eli Rohaeti) 


\section{PENDAHULUAN}

\section{Penggunaan plastik konvensional} berbasis minyak bumi yang terus meningkat dari tahun ke tahun menjadi permasalahan serius yang perlu dicari solusinya. Plastik konvensionalini sulit diurai oleh mikroorganisme dalam tanah, sehingga mengakibatkan jumlah limbah yang makin menumpuk (Handayani dan Wijayanti, 2015).Dampak yang muncul berupa pencemaran lingkungan memberikan ancaman serius bagi kesehatan manusia. Beberapa langkah strategis telah dilakukan pemerintah untuk menekan angka penggunaan plastik, salah satunya adalah dengan mengenakan biaya tambahan untuk setiap penggunaan plastik. Namun, langkah tersebut belum terlalu memberikan efek positif dalam usaha pengurangan jumlah limbah plastik.

Terkait dengan hal tersebut, saat ini secara intensif dikembangkan material kemasan yang mudah diurai oleh mikroba dalam tanah yang disebut dengan bioplastik. Bioplastik merupakan biopolimer alami yang ramah lingkungan dan berpotensi untuk dijadikan bahan subtitusi plastik konvensional. Biopolimer ini dapat disintesis dari biomaterial yang relatif mudah diperbaharui sepertipati, selulosa, protein, lignin, dan kitosan (Reddy, dkk., 2013; Rhim, dkk., 2013). Dari beberapa biomaterial tersebut, pati telah menarik perhatian para peneliti untuk dijadiakn bahan dasar pembuatan bioplastik karena memiliki keunggulan di antaranya harganya murah, mudah diperoleh, dan dapat terkomposkan tanpa menghasilkan residu yang bersifat toksik (Xie, dkk., 2013).

Namun, bioplastik berbasis pati memiliki karakterfisik dan mekanik yang tidak terlalu baik yaitu bersifat kaku dan rapuh sehingga perlu digunakan zat aditif untuk meningkatkan kualitasnya (Choi, dkk., 1999). Salah satu zat aditif yang dapat digunakan adalah bahan pemlastis,yaitu bahan organikyang berguna untuk memperkecil tingkat kekakuan dari polimer. Zat ini memiliki berat molekul rendah dan berfungsi untuk meningkatkan fleksibilitas suatu polimer (Wypych, 2004). Terkait dengan itu, 1,4-butanadiol dan polietilen glikol (PEG) 1000 merupakan bahan pemlastis yang telah digunakan untuk meningkatkan tingkat keelastisan film bioplastik berbasis pati (Zhai, dkk., 2003; Róz, dkk., 2006). Penambahan kedua zat ini merupakan Pengaruh Penambahan 1,4-Butanadiol dan Polietilen Glikol (PEG) 1000 terhadap Kemudahan Biodegradasi Bioplastik dari Biji Nangka (Artocarpus heterophyllus) 
salah satu cara untuk memperbaiki sifat fisik dan mekanik bioplastik berbasis pati tersebut.

Sebagai polimer yang mudah terdegradasi, penambahan pemlastis tentu akan mempengaruhi degradibilitas bioplastik berbasis pati. Sehingga diperlukan suatu studi untuk mengetahui perilaku degradasi bioplastik berbasis pati serta pengaruh penambahan pemlastis terhadap proses degradasi tersebut. Hal ini berkaitan dengan berapa lama material bioplastik tersebut akan terdegradasi oleh mikroorganisme dalam tanah. Dalam penelitian ini, pati yang digunakan berasal dari biji nangka (Artocarpus heterophyllus), mengingat pemanfaatan pati dari biji nangka belum begitu maksimal. Kajian mengenai hal ini sangat penting karena akan membantu pembuatan desain bioplastik berbasis pati untuk tujuan lain atau berbahan dasar lain dengan tingkat degradasi yang telah diketahui.

\section{METODE PENELITIAN}

\section{Alat}

Alat-alat yang digunakan adalah blender, $\mathrm{pH}$-meter, penyaring, timbangan analitik, bak fermentasi, kompor, pengaduk, dan FTIR Shimadzu-8300

\section{Bahan}

Bahan yang digunakan adalah biji nangka, asam asetat pa, aquades, gula pasir, urea, Acetobacter xylinum, 1,4-butanadiol, dan PEG 1000.

\section{CARA KERJA}

\section{Tahap Pembuatan Nata}

Sebelum membuat bioplastik, bahan-bahan organik diubah terlebih dahulu menjadi nata. Dalam hal ini yang digunakan dalam percobaan adalah parutan

biji nangka. Parutan biji nangka tersebut selanjutnya di rebus sampai mendidih. Pada saat perebusan, dilakukan penambahan gula pasir sebanyak 2,5\% dan urea $0,5 \%$ dari banyaknya larutan. Setelah mendidih, dilakukan penyaringan untuk mendapatkan sari dari bahan hasil perebusan. Larutan yang sudah disaring didinginkan. Setelah dingin, dilakukan penambahan starter Acetobacter xylinum dan asam asetat guna menjaga $\mathrm{pH}$ dalam kisaran 3,0-4,0. Selanjutnya, untuk mengetahui pengaruh penambahan bahan pemlastis terhadap sifat mekanik bioplastik maka ditambahkan larutan 1,4-butanadiol dan PEG 1000. Larutan hasil penyaringan difermentasikan melalui perlakuan fermentasi selama 5 hari.

Pengaruh Penambahan 1,4-Butanadiol dan Polietilen Glikol (PEG) 1000 terhadap

Kemudahan Biodegradasi Bioplastik dari Biji Nangka (Artocarpus heterophyllus) 


\section{Tahap Pengeringan}

Tahap pengeringan nata meliputi:

a. Pengepresan nata menjadi bentuk film.

b. Pengeringan nata selama dua hari menjadi film dengan cara dianginanginkan dan tidak terkena cahaya matahari langsung.

\section{Tahap Karakterisisasi Bioplastik}

a. Uji Biodegradabilitas

Uji biodegradabilitas dilakukan dengan cara meletakkan sampel bioplastik dalam tanah yang mengandung pupuk kandang. Setelah sepuluh hari, sampel diambil, dibersihkan kemudian ditimbang.Pada proses biodegradasi, uji standar yang dapat dilakukan adalah uji kehilangan massa dan laju kehilangan massa dalam kurun waktu tertentu.Nilai tersebut dapat dihitung menggunakan persamaan (1):

Kehilangan massa $=\frac{W_{i}-W_{f}}{W_{i}} \times 100 \%$

dengan

$\mathrm{W}_{\mathrm{i}}=$ massa sampel sebelum diinkubasi.

$\mathrm{W}_{\mathrm{f}}=$ massa sampel sesudah

dibiodegradasi.

Adapun penentuan laju kehilangan massa

(v) dapat dihitung dengan menggunakan persamaan (2)

$$
v=\frac{w_{i}-w_{f}}{\Delta t}
$$

Pengaruh Penambahan 1,4-Butanadiol dan Polietilen Glikol (PEG) 1000 terhadap

Kemudahan Biodegradasi Bioplastik dari Biji Nangka (Artocarpus heterophyllus) 
penambahan 1,4-butanadiol dan PEG 1000 dengan konsentrasi $0,5 \%$ dan $1.0 \%$. Dalam penelitian ini, penggunaan butanadiol dan PEG 1000 dengan konsentrasi di atas 1,0\% mengakibatkan tidak terbentuknya lapisan pelikel bioplastik, hal ini karena aktivitas Acetobacter xylinum terganggu jika konsentrasi bahan pemlastis tersebut terlalu tinggi.

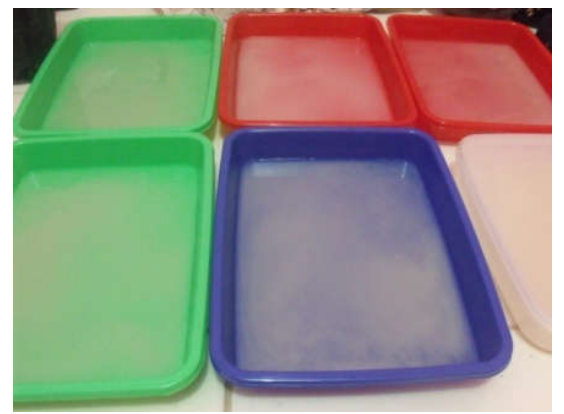

Gambar 1. Lapisan Pelikel Selulosa Hasil Fermentasi

Lapisan pelikel yang terbentuk kemudian dikeringkan pada suhu kamar untuk mendapatkan film bioplastik kering. Dalam hal ini, filmbioplastik keringmerupakan materialtransparan berwarna putih kekuningan sebagaimana disajikan pada Gambar 2.

\section{Analisis Biodegradasi}

Analisis biodegradasi film bioplastik dilakukan dengan menginkubasikan sampel yang berukuran 2 x $2 \mathrm{~cm}$ di dalam tanah yang mengandung pupuk kandang. Inkubasi ini dilakukan di dalam wadah plastik terbuka pada suhu kamar selama 10 hari. Setelah proses inkubasi selesai, sampel diambil, dibersihkan, ditimbang, dan dihitung pengurangan massanya untuk mengetahui nilai kehilangan massa dan lajunya. Hasil perhitungan tersebut ditunjukkan pada Tabel 1.

Adanya proses degradasi oleh mikroorganisme dalam media inkubasi ditandai dengan bertambahnya persen kehilangan massa pada setiap sampel. Berdasarkan data persen kehilangan massa pada Tabel 1, dapat diketahui bahwa semua film bioplastikyang diuji mengalami penurunan massa, hal ini karena dalam media perlakuan terdapat mikroorganisme yang mengurai film bioplastik (Rohaeti, 2009), sehingga dapat dikatakan semua sampel film bioplastik dapat terbiodegradasi dalam waktu 10 hari. 

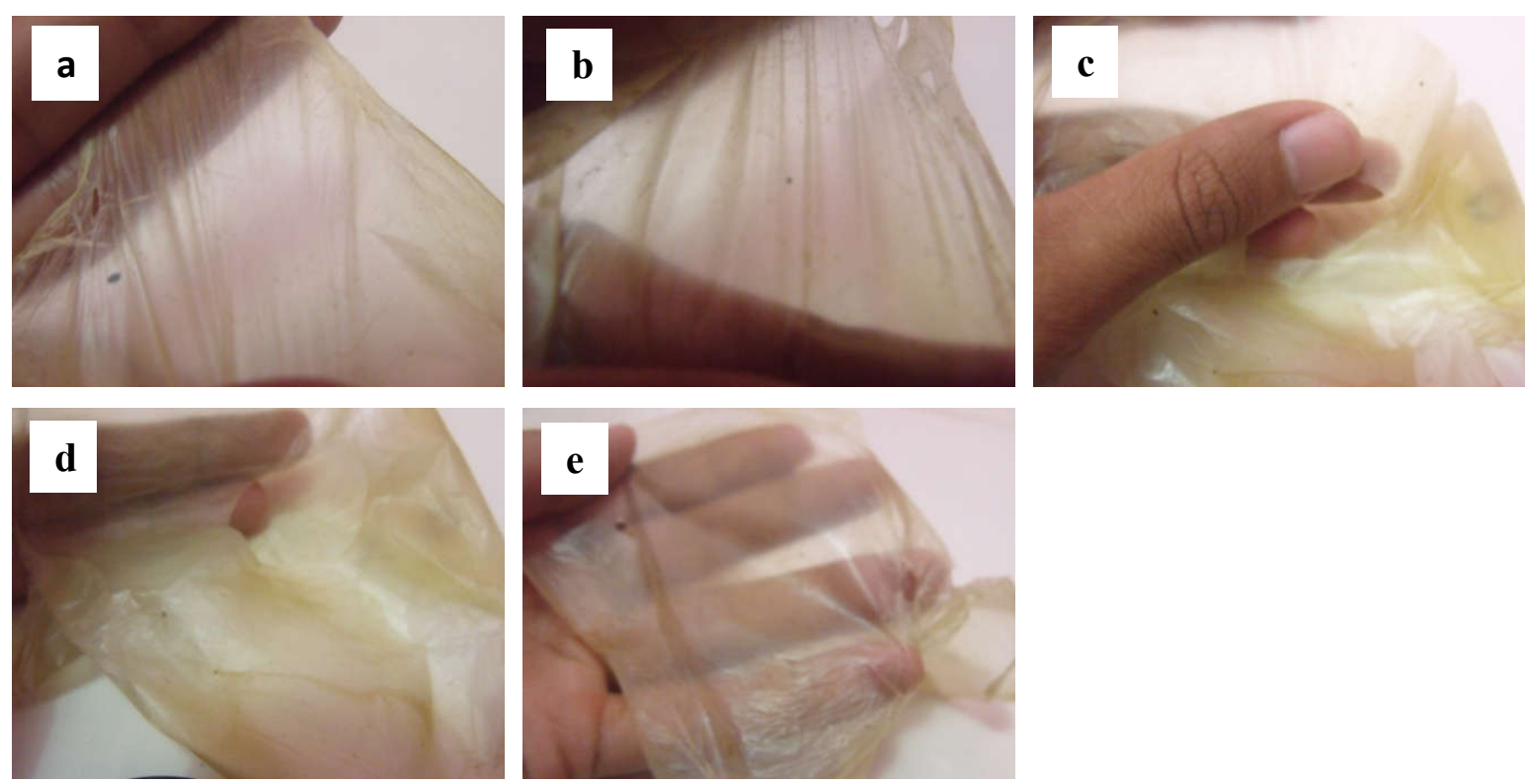

Gambar 2. Film Plastik Biodegradable dengan: (a) Tanpa Perlakuan; (b) Penambahan Butanadiol 0.5\%; (c) Penambahan Butanadiol 1.0\%; (d) Penambahan PEG 1000 0.5\%; (e) Penambahan PEG 1000 1.0\%

Dalam hal ini, interaksi antara bahan aditif berupa 1,4-butanadiol dan PEG 1000 dengan selulosa mempengaruhi persen kehilangan massa masing-masing sampel. Penambahan PEG 1000 menambah laju biodegradasi sampai dengan $100 \%$, sedangkan dengan penambahan 1,4-butanadiol pada konsentrasi $0,5 \%$ lajunya bertambah, dan pada konsentrasi 1\% lajunya menurun. Laju kehilangan massa ini dipengaruhi oleh kemudahan bahan film bioplastik tersebut untuk diurai oleh mikroorganisme dalam tanah, semakin kuat ikatan-ikatan yang terjadi dalam film bioplastik, maka semakin sulit untuk diurai.

Tabel 1.Hasil Uji Biodegradasi

\begin{tabular}{clcccc}
\hline No. & Perlakuan & $\begin{array}{c}\text { Massa sebelum } \\
\text { inkubasi (g) }\end{array}$ & $\begin{array}{c}\text { Massa setelah } \\
\text { inkubasi (g) }\end{array}$ & $\begin{array}{c}\text { Kehilangan } \\
\text { massa (\%) }\end{array}$ & $\begin{array}{c}\text { Laju } \\
\text { Kehilangan } \\
\text { Massa (g/hari) }\end{array}$ \\
\hline 1 & Tanpa perlakuan & 10,00 & 0,15 & 98,50 & 0,98 \\
$\mathbf{2}$ & Butanadiol 0,5\% & $\mathbf{1 0 , 0 0}$ & $\mathbf{0 , 0 7}$ & $\mathbf{9 9 , 3 0}$ & $\mathbf{0 , 9 9}$ \\
3 & Butanadiol 1,0\% & 10,00 & 0,16 & 98,40 & 0,98 \\
4 & PEG 1000 0,5\% & 10,00 & 0,00 & 100,00 & 1,00 \\
5 & PEG 1000 1,0\% & 10,00 & 0,00 & 100,00 & 1,00 \\
\hline
\end{tabular}

Pengaruh Penambahan 1,4-Butanadiol dan Polietilen Glikol (PEG) 1000 terhadap

Kemudahan Biodegradasi Bioplastik dari Biji Nangka (Artocarpus heterophyllus) 


\section{Analisis FTIR}

Analisis FTIR digunakan untuk mengetahui gugus fungsi dari film bioplastik.Gugus-gugus fungsi ini berperan dalam kemudahan biodegradasi masingmasing sampel, karena setiap gugus fungsi mampu mengadakan interaksi dengan gugus fungsi yang berada disekitarnya. Analisis ini dilakukan untuk mengidentifikasi gugus fungsi yang terdapat dalam sampel film bioplastik tanpa perlakuan dan sampel film bioplastik dengan penambahan 1,4-butanadiol 0.5\%.

Pada Gambar 3(a) terdapat serapan pada bilangan gelombang $3451,59 \mathrm{~cm}^{-1}$ yang menunjukkan serapan dari ikatan O$\mathrm{H}$ yang berasal dari unit ulang glukosa; serapan pada bilangan gelombang 1641,03 $\mathrm{cm}^{-1}$ menunjukkan serapan ikatan $\mathrm{C}=\mathrm{O}$ pada ujung terminal glukosa; dan serapan pada bilangan gelombang $615,07 \mathrm{~cm}^{-1}$ menunjukkan serapan piranosa.

Melalui Gambar 3(b) dapat diketahui bahwa terdapat serapan pada bilangan gelombang 3441,08 $\mathrm{cm}^{-1}$ yang merupakan serapan dari ikatan $\mathrm{O}-\mathrm{H}$ dari monomer glukosa; serapan pada bilangan gelombang $2354 \mathrm{~cm}^{-1}$ menunjukkan serapan C-H; serapan pada $1638 \mathrm{~cm}^{-1}$ menunjukkan serapan $\mathrm{C}=\mathrm{O}$ pada ujung terminal glukosa; serapan pada 1107,04 $\mathrm{cm}^{-1}$ menunjukkan serapan ikatan $\mathrm{C}-\mathrm{O}-\mathrm{C}$ glikosidik dan bentuk piranosa.

Pada kedua spektra FTIR bioplastik tersebut dapat diamati bahwa serapan $\mathrm{OH}$ pada penambahan 1,4-butanadiol $0,5 \%$ lebih melebar dan intensitasnya lebih tinggi, hal ini disebabkan oleh adanya penambahan gugus $\mathrm{OH}$ dari 1,4-butanadiol yang berinteraksi dengan selulosa. Diperkuat lagi dengan adanya serapan di daerah $2354 \mathrm{~cm}^{-1}$ yang menunjukkan serapan C-H dari 1,4-butanadiol. Spektra tersebut menunjukkan bahwa penambahan 1,4-butanadiol dapat mengadakan interaksi dengan selulosa sampai dengan intra molekul, karena 1,4-butanadiol tidak hilang pada proses pencucian. 


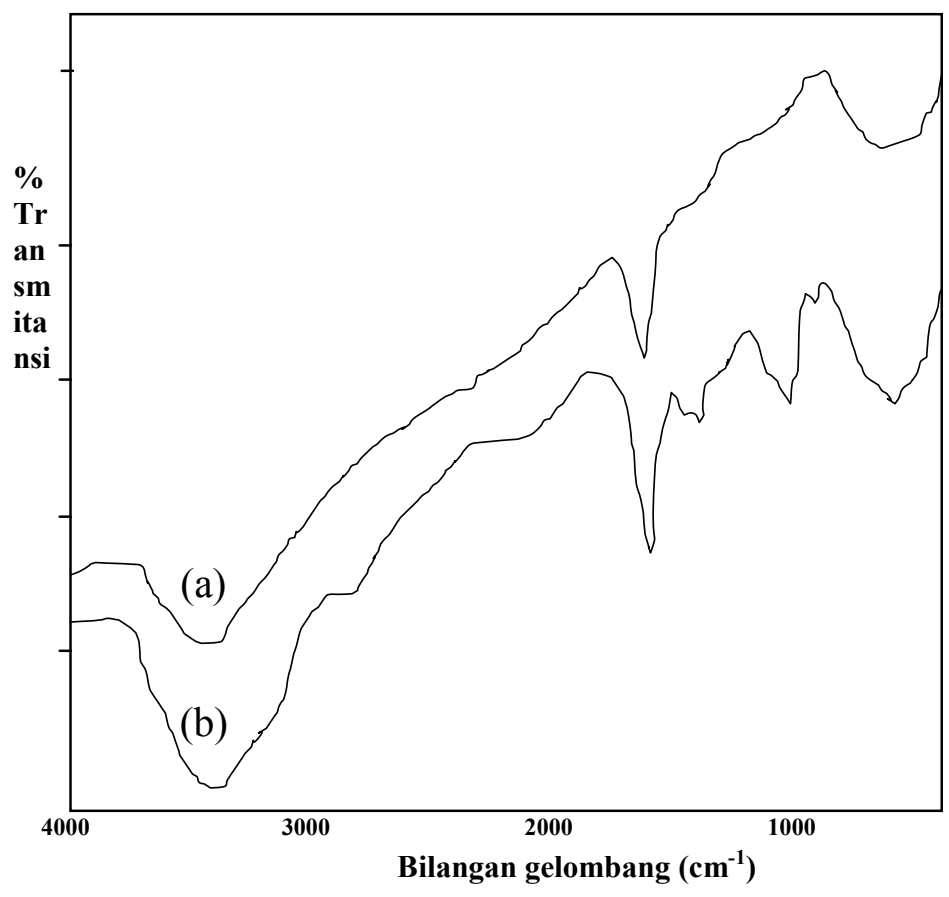

Gambar 3. Spektra FTIR sampel film bioplastik:(a) tanpa perlakuan; (b) dengan penambahan 1,4-butanadiol 0,5\%

\section{KESIMPULAN}

Penambahan zat pemlastis berupa 1,4butanadiol dan PEG 1000 tidak memberikan pengaruh yang terlalu signifikan terhadap biodegradabilitas film bioplastik dari pati biji nangka, karena seluruh nilai biodegradabilitasnya sama sama di atas 90\%. Penambahan PEG 1000 menambah laju biodegradasi sampai dengan $100 \%$, sedangkan dengan penambahan 1,4-butanadiol pada konsentrasi $0,5 \%$ lajunya bertambah, dan pada konsentrasi $1 \%$ lajunya menurun. Laju kehilangan massa ini dipengaruhi oleh kemudahan bahan film bioplastik tersebut untuk diurai oleh mikroorganisme dalam tanah, semakin kuat ikatan-ikatan yang terjadi dalam film bioplastik, maka semakin sulit untuk diurai.

\section{UCAPAN TERIMA KASIH}

Terima kasih kepada Direktorat Jenderal Pendidikan Tinggi, Kementerian Pendidikan Nasional, atas bantuan dana melalui hibah PKM-P 2011.

Pengaruh Penambahan 1,4-Butanadiol dan Polietilen Glikol (PEG) 1000 terhadap Kemudahan Biodegradasi Bioplastik dari Biji Nangka (Artocarpus heterophyllus) 


\section{PUSTAKA}

Choi, E.J., Kim, C.H. and Park, J.K., 1999. Synthesis and characterization ofstarch-gpolycaprolactonecopolymer. Macro molecules, 32(2),pp.7402-7408.

Da Róz, A.L., Carvalho, A.J.F., Gandini, A. and Curvelo, A.A.S., 2006. The effect of plastisizers on thermoplastik starch compositions obtained by melt processing. Carbohydrate

Polimers, 63(3), pp.417-424.

Handayani, P.A. dan Wijayanti, H., 2015. Pembuatan Film Plastik Biodegradable dari Limbah Biji Durian (Durio zibethinus Murr.).Jurnal Bahan Alam Terbarukan, 4(1), pp.21-26.

Hassan, E.A., Abdelhady, H.M., El-Salam, S.S.A. and Abdullah, S.M.2015. The Characterization of Bacterial Cellulose Produced by Acetobacter xylinum and Komgataeibacter saccharovorans under Optimized Fermentation

Conditions. BritishMicrobiology ResearchJournal, 9(3).

Mohammad, S.M., Rahman, N.A., Khalil, M.S. and Abdullah, S.R.S. 2014. An Overview of Biocellulose Production Using Acetobacter xylinum Culture.Advances in Biological Research, 8(6), pp.307313.

Reddy, M.M., Vivekanandhan, S., Misra, M., Bhatia, S.K. and Mohanty, A.K., 2013. Biobased plastiks and bionanocomposites: Current status and future opportunities. Progress in Polimer Science, 38(10), pp.1653-1689.

Rhim, J.W., Park, H.M. and Ha, C.S., 2013. Bio-nanocomposites for food packaging applications. Progress in Polymer Science, 38(10), pp.16291652.

Rohaeti, Eli. 2009. Karakterisasi Biodegradasi Polimer. Seminar Nasional Penelitian, Pendidikan, dan Penerapan MIPA: FMIPA UNY.

Wypych, G., 2004. Handbook of plasticizers. ChemTec Publishing.

Xie, F., Pollet, E., Halley, P.J. and Averous, L., 2013. Starch-based nano-biocomposites. Progress in Polimer Science, 38(10), pp.15901628.

Zhai, M., Yoshii, F. and Kume, T., 2003. Radiation modification of starchbased plastik sheets. Carbohydrate Polimers, 52(3), pp.311-317.

Pengaruh Penambahan 1,4-Butanadiol dan Polietilen Glikol (PEG) 1000 terhadap

Kemudahan Biodegradasi Bioplastik dari Biji Nangka (Artocarpus heterophyllus) 